\title{
Anachrony in Vladimir Nabokov's Lolita: A Study of the Novel's Narrative Tense Arrangement
}

\author{
$1^{\text {st }}$ Alsyifa Rifka Sabarini \\ Russian Studies, Faculty of Humanities \\ Universitas Indonesia \\ Depok, Indonesia \\ alsyifa.rifka@ui.ac.id
}

\author{
$2^{\text {nd }}$ Thera Widyastuti* \\ Literature Department, Faculty of \\ Humanities, Universitas Indonesia \\ Depok, Indonesia \\ thera.widyastuti@gmail.com
}

\begin{abstract}
This article represents a critical reading of the arrangement of the narrative tense in the storytelling of Vladimir Nabokov's Lolita (1955) [1]. Gérard Genette's [2] concept of narratology as a structuralist approach to literary criticism forms the theoretical grounding for this analysis. The study aims to explicate the plot and its narrative order, the storytelling techniques used in the novel, the process in which they generate certain narrative effects, and the narrator's temporal position vis-à-vis the story that is being recounted. The study employs descriptive methods to interpret textual facts and data obtained from the research object. The examination reveals that Lolita's plot is communicated using the framework of analepsis combined with achrony, an amalgamation that explains the novel's complex narrative structure. Achrony is also pivotal in suspending the significance of certain events in Lolita and the device thus creates substantial narrative impact. It delivers the essence of the novel, which is specifically engendered by the interactions between the initial narrative and the verified account tendered by the narrator of Lolita.
\end{abstract}

Keywords - literary criticism, narrative, narratology, order, structuralism

\section{Introduction}

Lolita, written by Russian émigré author, Vladimir Nabokov, is one of the most influential and controversial literary texts of the 20th century. Its publication triggered a major scholarly debate because of the unusual erotic passion embodied by its infamous protagonist. For the benefit of those unacquainted with the novel, Lolita recounts a middleaged professor Humbert Humbert's obsession with Dolores "Lolita" Haze, a twelve-year-old girl. The depressing and perhaps outrageous story is nonetheless also compelling in its beauty thanks to Nabokov's prowess of delineating characters with complex psyches, conflicts, and moral schemes. Thus, Lolita successfully evokes varied and opposing emotions and responses in its readers. In fact, the novel enjoyed so much literary success that it was even described as "the only convincing love story of our century" by Vanity Fair in 1986 [3]. It is therefore unsurprising that Vladimir Nabokov and Lolita retain their positions among the most popular and interesting subjects of literary research even decades after the novel was first published.

Besides the controversial nature of its theme, Lolita's narrative, especially in terms of the story's progression, is so thoughtfully organized that the novel's structure itself demands due academic attention. The development of Lolita's story entails the application of certain fundamental narrative strategies to create particular narrative effects. For instance, Lolita is presented to readers as a memoir written by the protagonist-narrator, Humbert. He does not make it easy for the average reader to grasp the progression of his account: the novel heavily and repeatedly incorporates flashbacks, narrative pauses, and even traps intended to trick its readers. These techniques contribute to the dispersion of the full significance of iterations and events across the entirety of the narrative. The narrator does not show any remorse for his misconduct in the first few chapters. He even shares an excerpt of his diary with the readers in Chapter 11 Part 1 , in which he explicitly describes an instance when he molested Dolores and achieved a sexual climax without her being aware. Despite the outrageousness of this act, he is proud of not stealing her innocence. However, as the story moves toward its end, he admits to his monstrous nature and acknowledges that he is a child molester, a kidnapper who destroyed Dolores' life. Interestingly, as an ostensible memoir, the events recounted in Lolita have presumably already occurred. The only new or current aspect of the novel pertains to Humbert's reflections-his "verified narrative"apropos the memoir.

The current study aims primarily to demonstrate the manner in which the relationships between the order of Lolita's plot and its organization at the narrative level contribute to the generation of particular narrative effects. This paper attempts to unravel the complexity of Lolita's narrative for a more systematic elucidation of the impact exerted by the novel's structure. To this end, it is essential for the paper to contemplate the device of anachrony or the discordance between the temporal arrangement (the order of the story) and the pseudo-temporal sequence (the order of the narrative). Storytelling techniques such as analepsis (flashbacks) and prolepsis (flash-forwards) employed by Nabokov in this novel among other devices also demand deliberation. In addition, the current study attempts to uncover the framework of the narrative order of Lolita and Humbert's temporal position in the story. It further intends to examine the narrative techniques that manifest in the plot and contemplate their respective narrative effects.

The focus of this research endeavor to examine Lolita's narrative validates its theoretical grounding in Gérard Genette's postulation of narratology as developed in the multi-volume Narrative Discourse: An Essay in Method [2]. In this text, Genette maps methods of narrative study through a detailed study of Proust's seven-volume 1927 novel, $A$ la Recherche du Temps Perdu (In Search of Lost Time) [4]. Genette distinguishes three aspects that are generally encompassed in the term narrative and that are inseparable in actual practice: the story, or the series of narrated events; the narrative, or the discourse that manifests in as the words displayed on a page; and the narration, or the act of storytelling that generates the narrative. 
Genette emphasizes that the three narrative facets interact with each other through three analytical categories and their elements: the narrative tense, which includes order, duration, and frequency; the narrative mood, which incorporates distance and perspective; and the narrative voice. While narrative tense and narrative mood operate within the story and the storytelling levels of the narrative, the narrative voice operates in both the narration and narrative components, or in the aspects of both storytelling and the story itself [2]. The present study inspects the anachrony in Nabokov's Lolita; it thus confines itself to the analytical category of the narrative tense, especially in the sense of its sequencing. Put differently, this paper attends specifically to the relationship between the order of the story and the order of the narrative. The paper will also demonstrate that Nabokov's Lolita also incorporates achrony - a complex type of anachrony comprising seconddegree prolepses or analepses.

The abundance of existing literary criticism using the structuralist framework on Nabokov's oeuvre, especially Lolita, has already been mentioned above. Leland de la Durantaye's "The Pattern of Cruelty and the Cruelty of Pattern in Vladimir Nabokov" (2006) [5] meticulously explains the motif of cruelty attributed to Nabokov by his admirers in literary circles across the globe. The essay identifies the cruelty that is presented as a theme in his work and that is also evident in Nabokov's views on art and literature. The use of signs and symbols in texts such as Lolita, Bend Sinister, and Ada are demonstrated to repeat patterns imprinted into the narrative structures of these texts. These designs make Nabokov's texts less accessible and more difficult to decode for the average reader. Finally, this essay elucidates Nabokov's usage of these patterns of cruelty in his work to help clarify the perceptual responses of general readers and enhance their understanding of Nabokov's work.

X. F. Zhang's "Structural Interpretation of Lolita" (2011) [6] analyzes Lolita through the structural semantics theory developed by A. J. Greimas [7] and through the interpretation of behavioral features in the novel's narrative grammar, a concept posited by Tzvetan Todorov [8]. Zhang's study helps readers to comprehend Lolita through the structuralist perspective. In particular, it reveals the binary opposition that underlies the conflicts in the novel: the pattern of searching-finding-losing-searching experienced by each character.

\section{Method}

Vladimir Nabokov's novel Lolita [1] and Gérard Genette's Narrative Discourse: An Essay in Method (1980) [2] form the corpus for this research project. First, this study determines the sequence of the narrative in Nabokov's Lolita by disclosing the patterns and the cardinal functions of the novel. To achieve this end, it utilizes an analysis system based on Barthes' postulation of the functional unit [10]. Subsequently, the discordance between the temporal order and the pseudo-temporal order of the novel is examined using the descriptive research methodology, which represents a fact-finding process that attempts an appropriate interpretation of the object of research [9].

In his essay, "An Introduction to the Structural Analysis of the Narrative" [10], Barthes describes an analysis system based on a functional unit, in which a narrative structure is classified into hierarchical components. Barthes differentiates the narrative structure into three interacting levels: function, action, and narrative. These levels are further subdivided into smaller interactive subcategories.

As a small component of the narrative structure, function acts as the seed that will develop the narrative, and that will soon operate at the level of the story. There are four types of functional units: cardinal, which acts as a hinge between sequences; catalyst, which connects the cardinal functions; indices, which provide information on the narrative atmosphere; and informant, which elucidates the space and time construct of the narrative. The catalyst, indices, and informant functions are bound loosely the narrative; however, while the cardinal functions are robustly tied together.

The cardinal function is not determined by its significance level, but by the interrelated nature of its implicative relationships within the narrative. The logical succession of cardinal functions that are related to each other is called the narrative sequence. The strong bonds are crucial to the definition of the narrative framework. Therefore, researchers who seek to discover the inherent structures of a narrative must attend to these cardinal bonds.

\section{Results and Discussion}

The plot of Lolita unfolds in an analepsis framework because the novel is formulated on the basis of a memoir. However, the first chapter of the novel begins in the present, or the actual time that Humbert starts to write the memoir with the inscription of variations of Dolores' name: Lo, Lola, Dolly, Dolores, Lolita. Before the narrative jumps back to his childhood in Chapter 2 Part 1, Humbert states that Lolita "happens" because she had a precursor, a girl-child named Annabel Leigh, his childhood sweetheart. At this point, he pauses the narrative to make room for analepsis using this following quote:

“Уважаемые присяжные женского и мужеского пола! Экспонат Номер Первый представляет собой то, чему так завидовали Эдгаровы серафимь-худо осведомленные, простодушные, благороднокрылые серафимы... Полюбуйтесь-ка на этот клубок терний.” (8) [1]

"Ladies and gentlemen of the jury, exhibit number one is what the seraphs, the misinformed, simple, noble-winged seraphs, envied. Look at this tangle of thorns."

The narrative then turns to Humbert's childhood and his brief, tragic love story involving Annabel Leigh. Thus, the first sequences of a past story are inserted immediately after Humbert a narrative pause into a present narrative that precedes this flashback. Genette's definition allows the first narrative of Lolita to be determined as follows: the time when Humbert began writing the memoir is 1952 [1]. From this first narrative, the storyline appears to move forward, back to the point when Humbert completes the memoir, unraveling the recounted story sequence by sequence.

Since Humbert opens the story in 1952 and then moves to the year of his birth (1910), the analepsis spans 42 years from the temporal field of the first narrative. It may thus be termed an external analepsis. Before he really jumps into his 
memory of Lolita, Humbert recalls events that, to his mind, caused his consuming obsession for Lolita: his summer fling with Annabel and their passionate desire for each other haunts him. Humbert keeps looking for that child years after she dies in 1923, and long after he himself has left his childhood behind. Twenty-four years later, after leaving France for The United States of America, Humbert becomes convinced that his "Annabel curse" has broken when he first sees Dolores, the daughter of his widowed landlady, Charlotte Haze. Soon, Humbert marries Charlotte to gain easier access to Dolores. Their marriage, however, does not last long; Charlotte is killed in a tragic accident. Following Charlotte's tragic demise, Humbert gains full custody of Dolores, as per the prevailing laws. The exploitation begins at this juncture. He takes Dolores on long trips across America from motel to motel, leaving Ramsdale behind to cut off any remaining connections she may have left. This constant migration also allows Humbert to consummate his obsession with Dolores.

It is notable that Humbert "fills in" the narrative pause at the beginning of his memoir by enlightening the reader about antecedent sequences that lead to the iteration of the famous first line: "Lolita, light of my life, fire of my loins." For Humbert, the reminiscing about their intimacy through "those years" in motels across America and through their life together in Beardsley is a joyful exercise despite the painful memories that are evoked when those years are compared to his Lolita-less present. Because this analepsis is external, this act of recall never interferes with or influences the first narrative.

After the main story accomplishes its range from Humbert's childhood to his arrest, the extent of the analepsis is almost equal to its full span of 42 years, which makes it a complete analepsis. The narrative movement completes a perfect round trip to retell the preceding events of the narrative in entirety. In Lolita, the analepsis serves to recover a person and recall historical events that lead to the iteration that begins the first narrative. Further, the main events in Lolita take place through flashbacks, and these flashbacks are so frequent that the reader never consciously realizes that Lolita is herself just a reminiscence, a remembered figment of Humbert's past about which we only know from his present account.

However, to claim that analepsis is the only component of Lolita's structure would be an oversimplification. As one attends more closely to the narrative structure, one finds a more complicated temporal structure embedded within it. One begins to discover the prolepses within the analepsis framework: these strategically become "hidden pieces" that are intentionally left unanswered until they are revealed in the advanced stages of the novel. The following paragraphs briefly describe the most notable prolepses within the analepsis framework that influence the narrative movement in Lolita.

Humbert anticipates the reader at several instances in the early stages of the novel, stating that he is a killer, but these statements are so playful that they come across as jest.

\footnotetext{
"Можете всегда положиться на убийиу в отношении затейливости прозы." (8) [1]
}

"You can always count on a murderer for a fancy prose style."

Humbert's poetic prose seems to negate the significance of the very statements he makes. Later, the reader finds that he killed Quilty and realizes that his nonchalant statements are not jokes. Interestingly, just like in detective novels that deduce results at the beginning of the story, the reader knows from the beginning of Lolita that someone has indeed been killed and that Humbert has killed someone. However, the reader must wait until Chapter 34 Part 2 to discover for certain and in detail that Humbert killed Quilty, who had "cheated him of his redemption," to take his revenge.

It is natural for a prolepsis to briefly allude to future events; it often refers in advance to an event that will be told in full in its due place - a repeated prolepsis [2]. As mentioned earlier, this prosthesis acts as the seed, the significance of which is not realized until much later when the phenomena mentioned earlier are fully revealed. This intentional tactic interweaves narratives that they refer to and that are referred to by planting brief expectations in the reader's mind about what is happening or will be happening later, even though the expositions are physically separated by several chapters or even sections.

The subtle mentions of Quilty throughout Lolita act as simple markers that do not arouse real anticipation and that earn their power of signification later through a flashback. Quilty has always been with the reader, and with Humbert, even during The Enchanted Hunter episode, when Humbert and Dolores engage in their first sexual encounter in Chapter 27 Part 1.

“- Посмотри, как он похож, как невероятно похож на Куильти”, [...]

- На кого - на намего толстого дантиста?” - “Да глупости”, сказала она, поперхнувшись смехом, "я говорю о том писателе, который на папиросных рекламах”. (90) [1] $[\ldots]$

“"Does not he look exactly, but exactly, like Quilty?"

"Like our fat Ramsdale dentist?"_-CCourse not," she said with a splutter of mirth. "I meant the writer fellow in the Dromes ad.",

The mention of Quilty throughout the novel prepares both Humbert and the reader to deal with future situations involving Quilty, such as when Lolita expresses her love for Quilty, or when Humbert murders him. However, in the beginning, true to the temporally appropriate ignorance, Humbert refers to Quilty as "Detective Trapp," the "police," or "Uncle Gustave" because Quilty's appearance reminds Humbert of his uncle Gustave Trapp. In narratology, these techniques are called snares because they trick the reader into forming false expectations about the actual occurrence (77). [2]

“Хочу написать еще несколько слов о г-же Гумберт, покуда пишется (скоро предстоит тяжкая катастрофа).” (60) [1]

"A few words more about Mrs. Humbert while the going is good (a bad accident is to happen quite soon)." 
Charlotte's death is also given an advance notice through a subtle hint in Chapter 19 Part 1, though its details are provided only in Chapter 23 Part 1. This death represents one of the novel's seminal events: Charlotte's death enables Humbert to take Dolores and wander through the United States, avoiding a return to Ramsdale so he can consummate his forbidden love and his consuming obsession.

The instances of analepsis embedded in the analeptic framework of Lolita can also explain the paralipsis that they reference. This device exposes the narrator's temporal position in the story, reveals the focal events of the story, and also generates the most significant narrative effects. In Chapter 29 Part 2, two years after Dolores disappears from the hospital, it is revealed that Humbert visited her when she was pregnant and married to Dick Schiller. This key event reveals the principal occurrences of the story: Quilty's presence permeates the novel through paralipsis, advanced mentions, or even traps.

When Dolores confesses that she ran away with Quilty, who subsequently dumped her after she refused to participate in his child pornography, Humbert recalls in Chapter 20 Part 1 past moments when Charlotte, he, and some family friends went swimming in Lake Hourglass. They were talking about Quilty and his inappropriate behavior with a child, but that conversation soon stopped [1]. At that point, Humbert realizes Quilty's presence on their trip across the United States all along. Quilty is the "stalker," the "detective," or the "policeman" who had aroused Humbert's suspicions since their stay in Beardsley and until they began their second, long journey, leaving Beardsley on Dolores' request. Quilty is the "Uncle Gustave" who checked Dolores out from the hospital in Elphinstone (G'29). In other words, the interwoven pattern of Humbert's suspicions and the pieces alluded to hitherto in the prolepses is revealed this point, explaining and connecting the jumbled pieces of the story that has always lain before the reader's eyes.

Although Humbert never personally knew Quilty, he is familiar with the character since Quilty is always vaguely present in the background. Humbert even feels that the readers have long guessed the identity of this mysterious figure is [1]. For example, Humbert does not question Dolores when she asserts in Chapter 15 Part 2 that Clare is an old woman. However, after his reunion with Dolores in Chapter 29 Part 2, he cogitates and understands that she lied to cover up Quilty's identity. When Humbert recalls his first encounter with Quilty in The Enchanted Hunter may be cited as another example: Humbert does not expend much thought to the encounter when it occurs, but realizes two years later that Quilty had been following them ever since. These analepses serve to help Humbert's narrative retrace its own path. Such narrative allusions to the narrative's own past alter the implications of Quilty's casual, and almost decorative, presence throughout the narrative. Readers write off Quilty as an insignificant presence because he seems merely to be an acquaintance of the Haze family and a celebrated playwright. Ultimately, they discover that Quilty is the only man Lolita had loved, the stalker who communicated with Lolita on the long journey with her stepfather, and a pedophile.

This type of repeating analepsis can also be found in Humbert's attitude toward his general story about Lolita.
Remorsefully, Humbert realizes he had treated Lolita merely as an object of his obsession, as his sex object [1]. This contrition contradicts the first few chapters of the novel in which Humbert explicitly sexualizes the twelve-year-old Dolores. For instance, in Chapter 15 Part 1, Humbert thinks about how disgusting it would be if Lolita grew up too soon into a woman [1]. When Humbert writes the memoir, when all the events have occurred, he realizes that even though she is no longer a nymphet, he still loves her more than anything he could ever imagine.

“Неистово хочу, чтобы весь свет узнал, как я люблю свою Лолиту, эту Лолиту, бледную и оскверненную, с чужим ребенком под сердием, [...], все еще мою, мою." (197) [1]

"I insist the world know how much I loved my Lolita, this Lolita, pale and polluted, and big with another's child, but still gray-eyed, [...], still mine."

The fact that Dolores' life did not get better-in fact, got even worse-after she left Humbert for "good" haunts him for the rest of his life. Humbert's remorse intensifies as his story comes to an end. He repudiates his initial obsession. He admits that his conduct had taken away Dolores' childhood and innocence and had also ruined her life.

"Но ужсасная сушность всего этого вопроса вот какая. Моя шаблонная Лолита за время нашего с ней несльханного, безнравственного сожительства постепенно пришла $к$ тому, что даже самая несчастная семейная жизнь предпочтительна пародии кровосмесительства - а лучше этого в конечном счете я ничего и не мог дать моей бездомной девочке." (204) [1]

"But the awful point of the whole argument is this. It had become gradually clear to my conventional Lolita during our singular and bestial cohabitation that even the most miserable of family lives was better than the parody of incest, which, in the long run, was the best I could offer the waif."

These lines indicate the double narrative that straddles between Humbert's initial thoughts about Dolores-an obsession, a sex object, Annabel's successor-and his verified narrative after he attains the awareness that he has ruined Dolores' life. Of course, molesting an under-age child is wrong and can never be deemed to be love, but the narrative deferring its significance is labeled enigma in narratology. The reader initially regards Humbert a heartless criminal. After becoming privy to Humbert's verified narrative, the reader is charmed by the fact that the heartless criminal has a conscience, just like any other human being. This enigma, then, disperses meaning throughout the narrative structure of Lolita, seducing the reader to immerse in Humbert's sins and psyche, amalgamating the essence of the novel through Humbert's initial and verified narratives that accord new perspective after the narrator-protagonist understands the significance of past events that once seemed paltry.

\section{Conclusions}

By identifying the discordance between the arrangement of the narrative and the sequence of the story in Vladimir Nabokov's Lolita by [1], this paper has evinced that the story 
is recounted through analepsis that encompasses seconddegree prolepses and analepses. The reach defines the analepsis as external and its extent renders it complete with the first narrative iteration acting as an advance conclusion. The analepsis elucidates the events that lead to the conclusion. The second-degree prolepses and analepses are repetitive motifs that briefly allude to phenomena and events that are later more thoroughly described. The technique of paralipsis also exerts a major influence on the narrative: like irony, it simultaneously depletes and emphasizes the significance of phenomena and occurrences through their advance mentions and announcements. Prolepsis interweaves the narrative elements that refer and are referred to by directing the reader's expectations even though the mentions could physically occur chapters apart.

The second-degree repeating analepses within the analepsis framework most influences Lolita's storytelling. Repeating analepses trace the narrative's path to refute past statements and to replace previous statements with new iterations or to refurbish them with new significations. This effect becomes evident when Humbert compares the past and the present, and the essence of the novel is generated through the dispersion of the meaning of Humbert's past and present values. In narratology, this deferment of signification is called enigma: the implications of the narrative elements of the past are suspended for the reader and are revealed in full in their due place and time.

\section{References}

[1] Nabokov, Vladimir. (1955). Лолита (Lolita). Florida: ABC Atticus.
[2] Genette, Gérard. (1980). Narrative Discourse: An Essay in Method. New York: Cornell University.

[3] Rezzori, Gregor von. (1986). "In Pursuit of Lolita," Vanity Fair.

[4] De la Durantaye, Leland. (2006). "The Pattern of Cruelty and the Cruelty of Pattern in Vladimir Nabokov: Leland De La Durantaye." The Cambridge Quarterly (vol. 35, no. 4) JSTOR http://www.jstor.org/stable/42971758

[5] Zhang, X. F. (2011). A Structuralist Interpretation of Lolita.

[6] Santosa, Puji. (2015). Metodologi Penelitian Sastra: Paradigma, Proposal, Pelaporan dan Penerapan (Literary Research Methodology: Paradigms, Proposals, Reports and Application). Yogyakarta: Azzagrafika.

[7] Barthes, Roland, \& Duisit, Lionel. (1975). An Introduction To The Structural Analysis Of Narrative. New Literary History, (vol. 6, no. 2.) JSTOR, doi:10.2307/468419.

[8] Abrams, M. H. (1979). The Mirror and the Lamp: Romantic Theory and the Critical Tradition. New York: Oxford University Press.

[9] Culler, Jonathan. (1980). "Foreword". Narrative Discourse: An Essay in Method, Gerard Genette, Cornell University.

[10] Fludernik, M. (2006). An Introduction to Narratology. New York: Routledge.

[11] Genette, Gerrad. (1988). Narrative Discourse Revisited. New York: Cornell University.

[12] Kuntjojo. (2009). Metodologi Penelitian (Research Method). Kediri: Self-Published.

[13] Nabokov, Vladimir. (2011). Lolita. Jakarta: Serambi.

[14] O’Neill, Patrick. (1996). Fictions of Discourse: Reading Narrative Theory. Toronto: University Of Toronto Press.

[15] Pradopo, Rachmat Djoko, et al. (2003). Metodologi Penelitian Sastra (Research Methodology in Literature). Yogyakarta: Hanindita Graha Widya.

[16] Sugiyono. (2012). Metode Penelitian Kuantitatif Kualitatif (Qualitative and Quantitative Research Methods). Bandung: Alfabeta.

[17] Tyson, Lois. (2006). Critical Theory Today. New York: Routledge. 